\title{
The Necessity of the Development of Standards for Renewable Energy Technologies in Nigeria
}

\author{
Vincent Nnaemeka Emodi, Samson D. Yusuf, Kyun-Jin Boo \\ Department of Technology Management, Economics and Policy Program, College of Engineering, Seoul \\ National University, Seoul, South Korea \\ Email: emeka50@snu.ac.kr
}

Received 9 September 2014; revised 28 September 2014; accepted 14 October 2014

Copyright (C) 2014 by authors and Scientific Research Publishing Inc.

This work is licensed under the Creative Commons Attribution International License (CC BY). http://creativecommons.org/licenses/by/4.0/

c) (i) Open Access

\begin{abstract}
Clean energy is vital for the sustainability of any economy in the world. Many industrialized nations have increased their production capacity of renewable energy while other countries lacking the technical expertise and resource have resorted to import these technologies. The imported technologies mostly have standards that are followed by the manufactures while others are manufactured cheaply and exported to developing countries that do not have adequate standards and certification bodies. Nigeria which is a fast growing country has no existing standards to check the influx of renewable energy technologies into the country. This study stresses the need for the development of standards for renewable energy technologies in order to prevent the importation of substandard renewable energy technologies in Nigeria. The study reviews the renewable energy potentials in Nigeria, introduces the concept of standardization and discusses the development of standards for renewable energy technologies.
\end{abstract}

\section{Keywords}

Standards, Standardization, Renewable Energy Technologies, Substandard

\section{Introduction}

Energy is an important factor for socioeconomic development and economic growth of any nation. Energy is usually stored in energy system which provides energy services. Energy services are desired and useful products, processes or services that result from the utilization of energy like lighting, powering of home-based appliances such as air-conditioner, refrigerators, and cookers for cooking. The energy chain to deliver these cited services 
begins with the collection or extraction of primary energy, which is converted to energy carriers suitable for the final consumers. These energy carries are utilized in energy end-user technologies to provide the desired energy services [1].

Energy sources are divided into conventional energy which is crude oil, natural gas and coal while non-conventional energy or renewable energy is solar, wind, hydro and biomass energy [2]. About $90 \%$ of the total energy supply in the world comes from conventional energy. Conventional energy contains mostly carbon which is the leading cause of global warming when released from crude oil products, gas and coal to the atmosphere [3]. The increase in global warming has indulged both the developed and developing countries to make a shift to renewable energy resources.

Most energy projection shows that the current and future world energy demand patterns are definitely not sustainable. However, the demand for energy will increase dramatically with developing countries consuming more and more energy. The only solution is to decouple the economic activities associated with conventional energy consumption [4]. This can be achieved by increasing the share of renewable energy in the energy consumption balance to enhance sustainability and improve the security of energy supply [5].

Renewable energy development in developing country aims at providing sustainable energy which will ensure the proper mitigation of energy scarcity and global warming. Renewable energy development has led to the increase in the manufacturing of renewable energy technologies such as solar panels, wind turbines and small hydropower (SHP). These technologies transform the energy stored in the sun, wind and hydro to energy which can be harnessed for human consumption.

Renewable energy that is being manufactured by different industries in various countries of the world has their specification and standards. When these technologies are imported into another country, standards are created by standards bodies in the importing country to ensure that the renewable energy technologies are reliable, compactable and safe for its citizens. Countries that don't have the technical expertise to manufacture renewable energy technologies have to import from other countries like China, South Korea, Japan, and the US etc. The countries that lack technical expertise are mostly in the African continent and they rely on imported technologies. These technologies are sometimes substandard and unreliable while others are even dangerous to the consumers and can cause fire outbreak which can destroy lives and property.

Nigeria, which is located in the West African region has been importing renewable energy technologies but has failed to ensure the establishment of standards for renewable energy by the Standards Organization of Nigeria (SON). This has led to the import of substandard renewable energy technologies into the country and has posed some dangers to her citizens who pay with their money hard earning but get low value for their money [6].

The question that arises now is: what should be done to ensure that this menace of the influx of substandard renewable energy technologies into the country is checked and how can a renewable energy standard be developed in Nigeria. This study seeks to answer the research questions by first reviewing the renewable energy resources in Nigeria, identifying the barriers to its development, provides strategies to enhance its development and then discusses on the development of renewable energy standards. The remainder of this paper is organized as follows. Section 2 reviews the renewable energy potentials in Nigeria including the policies, barriers and strategies to enhance its development. The concept of standardization is given in Section 3 which also includes the roles of standards and the standards regulatory agency in Nigeria. Section 4 discusses the development of renewable energy standards in Nigeria while conclusions are provided in Section 5.

\section{Renewable Energy Resources in Nigeria}

The global mindfulness of the phenomenon of climate change along with the anticipation of conventional energy scarcity have prompted many countries to develop a more sustainable energy system to cater for economic development and growth. Clean and environmental friendly energy can only be achieved through the proper utilization of renewable energy technology [7]. The renewable energy resources in Nigeria are as enormous as they are diverse [8]. However, the problem lies with the level of utilization which is very low. A long term commitment from the Government of Nigeria (GON) is crucial in implementing any kind of policies which will lead to renewable energy development, this can be seen in countries like Germany, Denmark, Japan and more recently, South Korea [9].

Nigeria's opportunity to improve the standard of living for its citizens, ensuring socioeconomic and political growth depends on the nation's ability to increase energy supply and proper utilization of its energy resources 
starting from the grassroots level [10]. Renewable energy technology has great potentials in alleviating the staggering energy situation currently being experienced in Nigeria. The potentials of renewable energy resources in Nigeria is about 1.5 times that of conventional energy resources in energy terms [11]. Table 1 [12] shows the renewable energy resources in Nigeria and they are discussed in the following subsections. It should be noted that biomass energy was not discussed in this study because biomass energy technology includes biomass plants and therefore this study only focused on solar, wind and hydropower.

\subsection{Solar Energy}

Among all the renewable energy resources available, solar is the most promising of them all due to its apparent limitless potentials. The energy that is radiated from the sun is about $3.8 \times 1023 \mathrm{KW}$ per second and most of it is transmitted radially as electromagnetic radiation which gives about $1.5 \mathrm{KW} / \mathrm{m}^{2}$ at the boundary of the atmosphere, a square meter of the earth's surface can receive solar power of about $1.5 \mathrm{KW}$ which averages about 0.5 daily [13].

Nigeria is located within a high sunshine belt and solar radiation is well distributed within the country. The intensity of solar radiation exhibits remarkable variation from the northern region to the southern region but is higher in the northern region as shown in Figure 1 [14]. With an average domestic load demand of $2324 \mathrm{Wh} / \mathrm{m}^{2}$ per day [15], Nigeria has a solar radiation potential of about $6500 \mathrm{Wh} / \mathrm{m}^{2}$ in the far north and $4000 \mathrm{Wh} / \mathrm{m}^{2}$ in the southern part of the country. Given an average solar radiation level of about $5500 \mathrm{Wh} / \mathrm{m}^{2}$, and prevailing efficiencies of commercial solar electric generators, then if solar collectors were employed to cover about $1 \%$ of Nigeria's land area of 923,773 KM, about $1850 \times 103$ GWh of solar electricity could be generated per year [16] [17].

The Energy Commission of Nigeria (ECN) has made some effort to harness the solar energy within Nigeria through the direct coordination of research and development activities undertaken by the Sokoto Energy Research Center (SERC) and the National Center for Energy Research and Development (NCERD) [18]. However, this effort has seen little or no significant impact in improving the energy situation in Nigeria. There is need for a strong industrial infrastructure which will be effective in the complete utilization of solar energy in Nigeria.

\subsection{Wind Energy}

Wind is a natural phenomenon related to the movement of air masses caused primarily by the movement of air masses caused primarily by the different solar heating of the earth's surface. Seasoned variations in the energy received from the sun affects the strength and direction of the wind. The ease with which aero turbines transform energy in the moving air to rotary mechanical energy suggest that the use of electrical devices to convert wind

\section{Table 1. Renewable energy resource in Nigeria (source: [12]).}

\begin{tabular}{|c|c|c|c|c|}
\hline \multirow{2}{*}{ Resource type } & \multicolumn{2}{|c|}{ Reserves } & \multirow{2}{*}{ Production } & \multirow{2}{*}{$\begin{array}{c}\text { Domestic } \\
\text { utilization } \\
\text { (natural units) }\end{array}$} \\
\hline & Natural units & Energy units (Btoe) & & \\
\hline Small hydropower & $3500 \mathrm{MW}$ & 0.34 (over 40 years) & $30 \mathrm{MW}$ & $30 \mathrm{MW}$ \\
\hline Large hydropower & $11,250 \mathrm{MW}$ & 0.8 (over 40 years) & $1938 \mathrm{MW}$ & $1938 \mathrm{MW}$ \\
\hline Wind & $2-4 \mathrm{~m} / \mathrm{s}$ at $10 \mathrm{~m}$ height (mainland) & $\begin{array}{l}0.0003 \text { (4 m/s@12\% probability, } \\
70 \text { m height, } 20 \text { m rotor, } \\
0.1 \% \text { land area,40 years) }\end{array}$ & - & - \\
\hline Solar radiation & $\begin{array}{l}3.5-7.0 \mathrm{kWh} / \mathrm{m}^{2} / \text { day (4.2 million } \\
\mathrm{MW} \text { h/day using } 0.1 \% \text { land area) }\end{array}$ & $\begin{array}{c}5.2 \text { (40 years and } 0.1 \% \text { land } \\
\text { area) }\end{array}$ & $6 \mathrm{MW}$ h/day & $6 \mathrm{MW}$ h/day \\
\hline $\begin{array}{l}\text { Biomass } \\
\text { fuel wood }\end{array}$ & $\begin{array}{l}11 \text { million hectares of forest and } \\
\text { wood land excess of } 1.2 \mathrm{~m} \text { ton/day }\end{array}$ & - & 0.120 million ton/day & $\begin{array}{l}0.120 \\
\text { million t/day }\end{array}$ \\
\hline Animal waste & 211 million assorted animals waste & - & $\begin{array}{c}0.781 \\
\text { million ton of waste/day }\end{array}$ & None \\
\hline $\begin{array}{l}\text { Energy crops and } \\
\text { agricultural residue }\end{array}$ & $\begin{array}{l}28.2 \text { million hectares of } \\
\text { arable land (=30\% of total land) }\end{array}$ & - & $\begin{array}{l}0.256 \text { million ton of } \\
\text { assorted crops/day }\end{array}$ & None \\
\hline
\end{tabular}




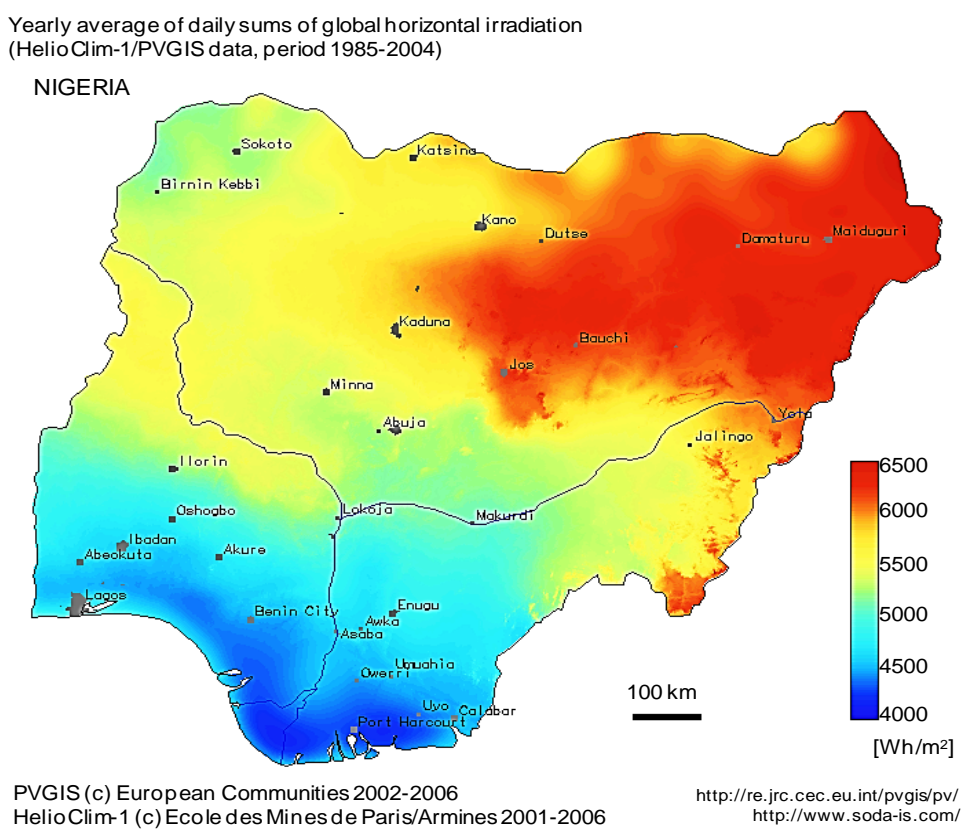

Figure 1. Yearly average of daily sun in Nigeria (source: [14]).

energy to electricity. For decades, wind has been used for water pumping and milling of grains [1].

Wind speed in Nigeria ranges from 4.0 to $6.0 \mathrm{~m} / \mathrm{s}$ in the northern part of the country and 2.5 to $4.0 \mathrm{~m} / \mathrm{s}$ in the southern part of the country as shown in Figure 2 [19]. With this amount of wind energy potential, small scale wind turbine could be installed to boost electricity supply and also be integrated into the national grid [8].

Despite Nigeria's exploitable wind energy resources, the present share of wind energy in the national energy consumption has been low with no available commercial wind farms but only standalone wind power plants for pumping water which were installed in 5 northern states during the 1960s. Also, a 10 MW wind turbine is currently installed in Katsina state to tap into the wind energy potentials in northern Nigeria. More effort should be put in to adequately harness the wind energy potential in Nigeria.

\subsection{Hydropower}

Hydropower generation is an important option to meet the growing demand for energy worldwide. In 2004, the world hydropower capacity was 2810 TWh and is projected to increase to 4903 TWh by the year 2030, with a growth rate of $1.8 \%$ per year, but its share still remains at $2 \%$ of the world energy supply [19]. Hydropower resources in Nigeria was first harnessed in 1962 by the Niger Dams Authority. Hydropower generation in Nigeria has substantial potential like the small, mini and micro water capacity for electricity generation but its total power contribution has declined in recent years due to some technical reasons [20]. Moreover, the use of oil and gas for power generation has had a negative impact on hydropower development in Nigeria [21].

Notwithstanding, small hydropower (SHP) is fast gaining rapid consideration due to its inherent advantages like in-excessive topography problems, low environmental impact, minimal civil works and high possibility for power generation along with irrigation and flood prevention. Research has been conducted by [22] and shows that about 738 MW of SHP could be harnessed from 278 sites based on the 1980 survey. However, the SHP potential in Nigeria is estimated at 3500 MW which represent about $23 \%$ of the total hydropower potential in the county.

Hydro capacity depends mainly on annual rainfall levels, with its distribution as well as the river systems which is subject to seasonal drought. In the northern part of Nigeria, the total rainfall is about $500 \mathrm{~mm}$ depth with a total precipitation which last for 3 months in a year while the southern part of the country has $3400 \mathrm{~mm}$ with a precipitation which may be less than 8 months a year [23]. Figure 3 shows the various water ways in Nigeria [24]. The government should do more to develop SHP to its full extent in order to improve power generation and reduce fiscal loads. 


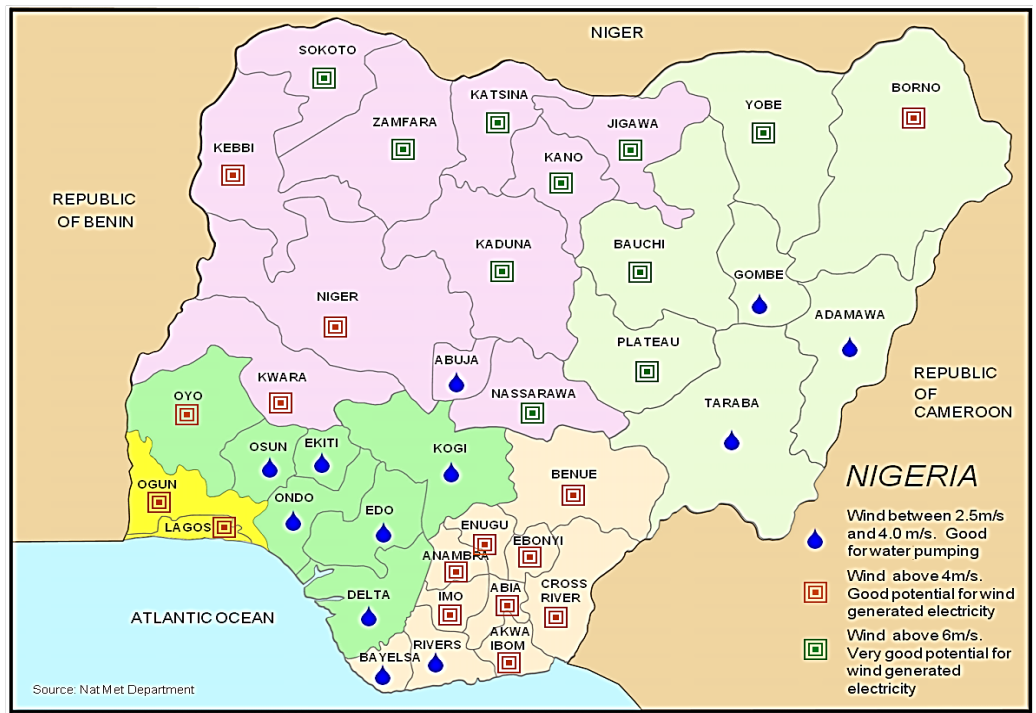

Figure 2. Wind energy locations in Nigeria (source: [19])

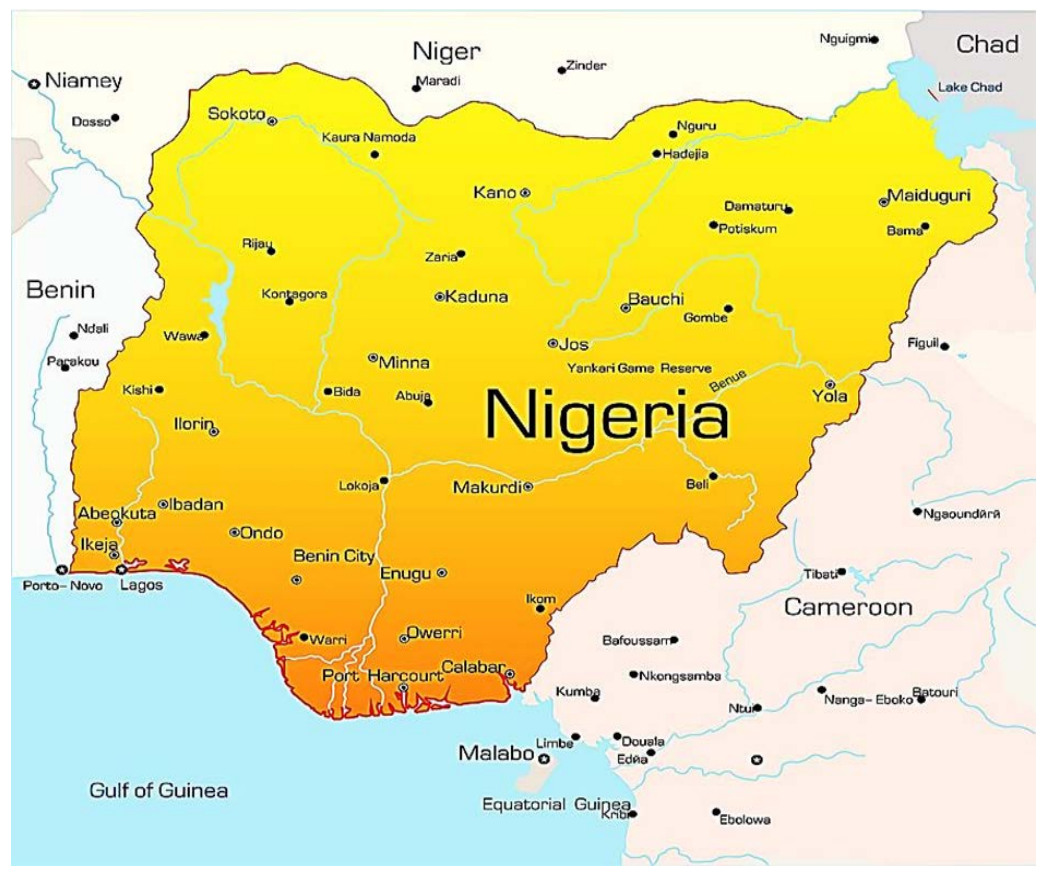

Figure 3. Nigerian water ways (source: [24]).

\subsection{Renewable Energy Policy}

The Energy Commission of Nigeria (ECN) has a mandate as an agency to develop and promote renewable energy technologies in Nigeria with strategic energy planning, policy coordination and performance monitoring for the entire energy sector. The ECN also has the responsibility of providing guidelines for the utilization of the various energy types for the different purpose and develop recommendations on new exploitable sources of energy. This includes renewable energy [25].

The Federal Government of Nigeria (FGN) in 2003 approved the National Energy Policy (NEP) which was facilitated by the ECN to articulate the sustainable exploitation and utilization of all energy sources. The key elements of the NEP on the development and utilization of renewable energy and its technologies are as follows: - To develop, promote and harness the renewable energy resources of Nigeria and incorporate all viable ones 
in the national energy mix;

- To promote decentralized energy supply, especially in rural areas, based on renewable energy resources;

- To deemphasize and discourage the use of wood as a fuel;

- To promote efficient methods in the use of biomass energy resources;

- To keep abreast of the international development in the renewable energy technologies and applications [26]. In 2006, the ECN also formulated the Renewable Energy Master Plan (REMP) as part of the strategy to reduce Greenhouse Gas (GHG) emission in Africa and address the challenges hindering the development of clean, reliable, secured and competitive energy supply [27] [28]. The REMP main objectives are given below:

- To develop and implement strategies that will achieve a clean reliable energy supply mechanism to develop the sector based on international best practices, to show case viability for private sector participation;

- To provide a comprehensive framework for developing renewable energy that will ensure:

$>$ Expanding access to energy services to Nigerians;

$>$ National agenda on emission reduction;

> Raising the standard of living, especially in the rural areas;

$>$ Stimulating economic growth, employment and empowerment;

> Increasing the scope and quality of rural services, including schools, information, health services, entertainment, and water supply and reducing rural urban migration [29].

The REMP aims at a 10\% renewable energy contribution to the national energy mix by 2020 through the adoption of a renewable portfolio standard (RPS). A RPS is a requirement for electric utilities to supply a specific amount of electricity to customers. This can be achieved through the purchase of renewable energy certificates from suppliers with a larger share of renewables in their energy mix. Other measures considered are the creation of innovative fiscal and market incentives to promote renewable energy industries, as well as preferential customs duty exemptions for imported renewable energy technology components. However, the lack of implementation of the master plan has meant that the $10 \%$ target of renewable energy mix in the energy supply cannot be achieved. The REMP is presently being subjected to a review, likely resulting in the setting of new targets. It will be essential that any future targets set for the attainment of a RE energy mix should be backed by legislation to ensure compliance, which is presently lacking.

Similarly, the National Policy and Guidelines on Renewable Electricity (NPGRE) was produced in 2006 with the main aim to expand the market for renewable electricity by $5 \%$ of the total electricity generation by 2016 . The strategy for achieving this target included: encouraging local manufacture and assembly of renewable energy components, provision of subsidies, and establishment of technical standards for RE components and introduction of feed-in-tariffs. The strategy is yet to be fully adopted as the reforms in the energy sector are still ongoing and decisions on tariffs and subsidies for renewable energy and other incentives have not yet been taken [8].

\subsection{Barriers to Renewable Energy Development}

Renewable energy in Nigeria has been inconsistent with minimal or no significant impact in the lives of Nigerians. Many barriers hinder the development and diffusion of renewable energy in Nigeria, including the following [30]:

- The lack of proper institutional framework which is due to the weak coordination between government ministries and agencies. These institutions are responsible for the promotion and development of renewable energy technologies in both the rural and urban areas;

- Low human capacity in the field of renewable energy development. Capacity building in the areas of training to install, operate, maintain and manufacturing of renewable energy is lacking in Nigeria;

- Non-existing Power Purchasing Agreements (PPA) plan for renewable energy generation to the utility grid. The PPA set the terms in which electricity is marketed and determines the delivery location, power characteristics, pricing, quality, schedule and terms of agreements including the punishment for breach of contract;

- Affordability of renewable energy technologies involves high cost of capital as compared to conventional energy. This has posed a lot of problems to investors who face the problem of high transaction costs and restricted to funds or capital. Consumers on the other side also face difficulty in purchasing these technologies because of its expensive cost of purchase;

- The lack of public awareness has negatively affected the development of renewable energy in Nigeria. Most 
Nigerians view renewable energy technologies as new technologies that are only for the wealthy in the society. This has made the most of the population who are low income earners to depend on conventional energy which is cheaper;

- Uncertified/poor quality renewable energy technologies now flood the markets in Nigeria. This has led to the withdrawal of most potential consumers because most renewable technologies easily damaged due to their low quality and the replacement parts or services usually cost a lot to obtain. Nigeria presently lack the proper standards in renewable energy technologies.

\subsection{Strategies to Enhance Renewable Energy Development}

As Section 2.5 highlighted the barriers to renewable energy development, this section will offer some strategies which will promote renewable energy development in Nigeria:

- Placing subsides on renewable energy technologies and also improving access to micro finance loans by potential consumers;

- The government should do more in the area of public awareness campaign to promote renewable energy technologies;

- Research and development in the area of renewable energy should be encouraged. This will enable the growth of human capacity and ensure that the technologies which are mostly imported can be manufactured in the country;

- A legally binding long term Power Purchase Agreement plan should be established in order to encourage developers of renewable energy. Also, other renewable energy development mechanisms like Feed-in-Tariffs (FiTs), Renewable Obligation (RO), Renewable Energy (green) Certificate (REC) and Renewable Portfolio Standard (RPS) should be initiated to facilitate the adoption of renewable energy technologies in Nigeria;

- Development of Renewable Energy Standards by the Standards Organization of Nigeria to check the influx of substandard renewable energy technologies into the country.

\section{Standardization}

The process of establishing and applying standards, standardization is defined by the International Organization for Standardization as "the process of formulating and applying rules for an orderly approach to a specific activity for the benefit and with the cooperation of all concerned, and in particular for the promotion of optimum overall economy, taking due account of functional conditions and safety requirements”. Standardization can be applied to specific products, as well as to, for example, norms, requirements, methods, terms, and designations commonly used in international trade and in science, engineering, industry, agriculture, construction, transportation, culture, public health, and other spheres of the national economy [31]. Standardization has a significant influence on the rate of development and level of production. Standardization provides the following advantages:

- Better product quality, reliable and durable life service;

- Components or parts mass production at a low cost;

- Availability of parts for replacement and maintenance;

- Less time and effort (productivity is high) for manufacture;

- Sizes and grades variations correction.

The concept of standardization uses numbers to limit unnecessary variations in sizes and grades of products, the general requirements indicates that such requirements are satisfied when it follows a geometric series. In international business, standards are applied to penetrate the markets in such a way that the products are made to fit into the requirements of any country. To do so, the need to follow the internationally recognized guidelines arises. Examples of products standard includes fuel economy and airbag specifications.

\subsection{Definition of Standards}

A "standard" can be defined as a specification (or a set of specifications) that relates to a product's attributes [32]. The International Organization for Standardization (ISO) defines standards as "a document, established by consensus and approved by a recognized body that provides, for common and repeated use, rules, guidelines or characteristics for activities or their results, aimed at the achievement of the optimum degree of order in a given context” [33]. In the WTO, definition for standards differentiates voluntary standards and technical regulation, 
where standards are voluntary and technical regulations mandatory with administrative provisions [34].

The IRENA defines standards as "a repeatable, harmonized, agreed and documented way of doing something. Standards contain technical specifications or other precise criteria designed to be used consistently as a rule, guideline, or definition. They help to make life simpler and increase the reliability and the effectiveness of many of the goods and services we use" [35]. Some economists have given various definition of standards, among them are; Alfred Marshall who defined standards as "customs" that recorded technical progress, firstly in an informal manner and then in a formal manner starting in industrial era [36]. David et al. (1990) defined standards as "a set of technical specifications adhered to be a producer, either tacitly or as a result of formal agreement" [37]. Richard et al. (1995) defined standards as "agreed external points of reference to which the physical and performance characteristics of technologies can be compared" [38].

From the above literatures we can understand that standards are published documents that establish specifications and procedures designed to maximize the reliability of the materials, products, methods, and/or services people use every day. Standards address a range of issues, including but not limited to various protocols to help maximize product functionality and compatibility, facilitate interoperability and support consumer safety and public health.

Standards form the fundamental building blocks for product development by establishing consistent protocols that can be universally understood and adopted. This helps fuel compatibility and interoperability and simplifies product development, and speeds time-to-market. Standards also make it easier to understand and compare competing products. As standards are globally adopted and applied in many markets, they also fuel international trade.

It is only through the use of standards that the requirements of interconnectivity and interoperability can be assured. It is only through the application of standards that the credibility of new products and new markets can be verified. In summary standards fuel the development and implementation of technologies that influence and transform the way we live, work and communicate.

\subsection{Process of Standards Development}

The process of developing a standard is typically facilitated by a Standards Development Organization (SDO), which adheres to fair and equitable processes that ensure the highest quality outputs and reinforce the market relevance of standards. SDOs, such as IEEE, IEC, ISO, and others, offer time-tested platforms, rules, governance, methodologies and even facilitation services that objectively address the standards development lifecycle, and help facilitate the development, distribution and maintenance of standards. While the goals of each SDO are essentially the same, each SDO applies its own rules, processes, and terminology to the standards development process. Typically, each SDO is comprised of boards, committees and staff who establish and maintain the policies, procedures and guidelines that help ensure the integrity of the standards development process, and the standards that are generated as an outcome of this process.

The development of a new standard is typically triggered by a formal request, submitted to an SDO by a Sponsoring Body (individual or entity, such as an industry society) for review and evaluation. The SDO mandates, oversees, and helps facilitate the process for standards development. The Sponsor for the standards project assumes responsibility for the respective area of standards development, including the organization of the standards development team and its activities. Once the SDO approves the request to develop a new standards development project, the Sponsor follows the SDOs rules and processes to recruit and assemble a collaborative team or "Working Group" to engage in active standards development (note: the term "Working Group" is an IEEE term. Working Groups may be called different names by the various SDOs, and may follow slightly different processes). Working Groups are comprised of individuals and/or entities (people, companies, organizations, non-profits, government agencies) who volunteer to support the development of standards [39].

Collectively, these volunteer participants carry a specific interest in a specific area of development as producers, sellers, buyers, users and/or regulators of a particular material, product, process or service. When a Working Group is formed the Working Group officers may either be elected by the Working Group members or appointed by the Sponsor. Consult the Sponsor's policies and procedures and the Sponsor's Working Group policies and procedures for details. Working Group officers oversee the standards development project in adherence to SDO rules and process, and remain accountable to the project Sponsor and the governance structure of the SDO itself.

Based on the rules and criteria established by the SDO, participants may contribute at varying levels to the 
standards development process. For example, the IEEE Standards Association (IEEE-SA) has established rules related to membership and participation, and employs a separate "Entity Standards Development Process" for standards that are sponsored by entities (such as corporations, governments, non-profits, associations or other organizations, etc.). Such rules help ensure that highly dedicated individuals lead participation and no one interest dominates the standards development process. Working Groups leverage these rules and guidelines and establish their own individual, organizational, communications and meeting structures, and govern work process, activities, consensus building, decision making, balloting and even financial reporting in accordance with SDO rules. To build consensus through democratic means, participants engage in meetings, draft and review position pieces, create and review presentations, examine data and engage in active discussion and debate to resolve outstanding issues.

These activities fuel the gradual definition of each standard, which is compiled into a draft standard that may undergo multiple revisions. Once a draft standard has been finalized, reviewed, and approved by the Working Group, it is submitted to the Sponsor for Sponsor balloting. Upon successful completion of the Sponsor ballot, the draft is submitted to the Review Committee (RevCom). The balloted draft is reviewed by RevCom and then submitted to the Standards Board for approval. After submission, review and acceptance, the approved standard is published and made available for distribution and purchasing within in a number of outlets, including through the SDO itself [39] [40].

It is important to remember that standards are "living documents", which may initially be published and iteratively modified, corrected, adjusted and/or updated based on market conditions and other factors. At any given point in time, therefore, a standard may be referred to as having a number of different "status" classifications.

These include (see Figure 4):

- Approved Project-An initial project request is approved, in stages of group formation.

- Active Project-An active standards development project.

- Withdrawn Project-A cancelled standards development project.

- Approved Standard-The standard is approved and published for public use.

- Withdrawn Standard-The standard is no longer market relevant or active.

- Superseded Standard - The standard has been replaced by a new standard.

In keeping with the standards development lifecycle, Working Groups may also go through periodic stages of activity or dormancy. Depending on where a standard is in its lifecycle a standard may be accompanied by supplemental documents that are produced by its respective Working Group. These may include errata (which address errors in the standard), amendments (which modify sections of the standard), corrigenda (which only correct errors or ambiguities in a standard), handbooks, tutorials and other related materials. Supplemental documents help interested parties better understand and apply the standard [39].

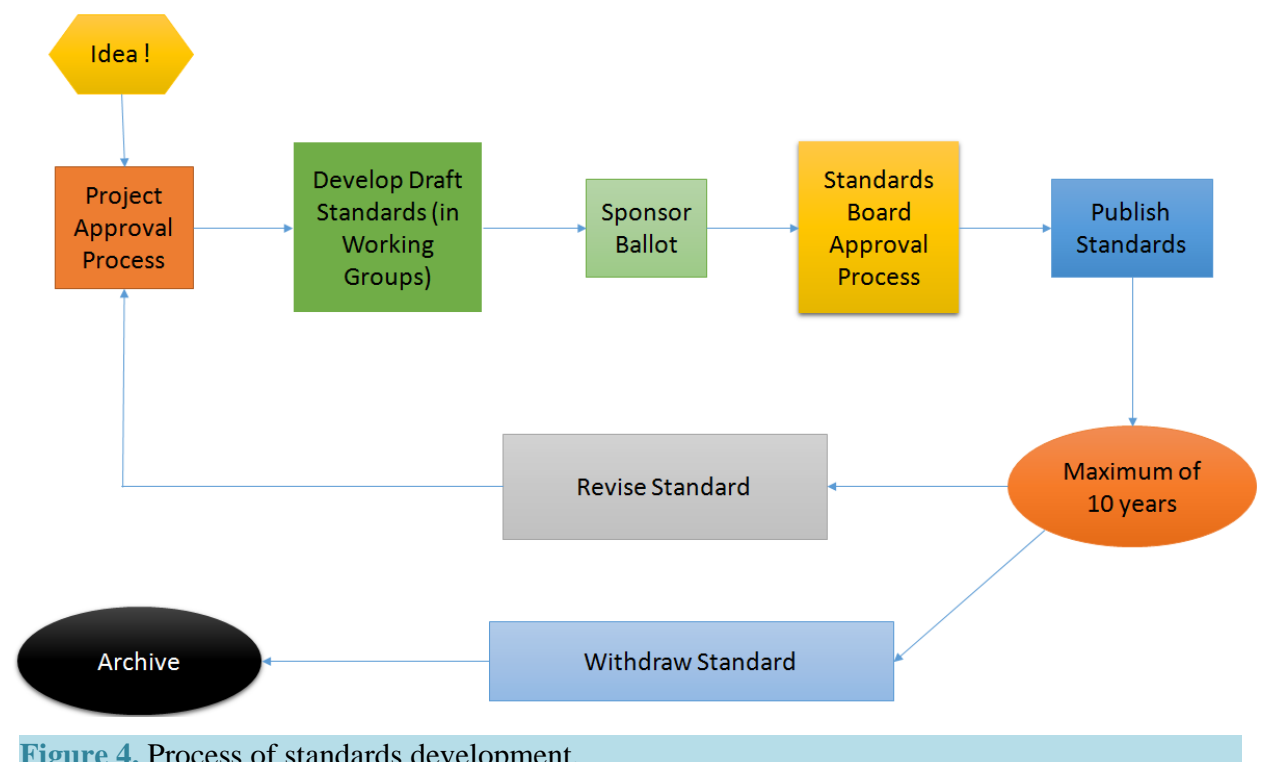

Figure 4. Process of standards development. 


\subsection{Roles and Functions of Standards}

Standards are established through government policies or consumer protection organizations to protect the consumers of various goods and services as most consumers have little or no choice in what they are offered. In rural communities in developing countries, consumers do not generally have the luxury of comparing features and selecting their suppliers or products from the Internet. Hence, the role of standards is to ensure that whatever product or service is provided to the consumers is fit for purpose, safe and has value. An important aspect of this protection is to ensure the product or service delivers as claimed, performs as specified, and is reliable, durable and safe. In many cases renewable energy standards and conformity assessment can be the catalyst in providing alternatives to systems which are sometimes unsafe, operate with low efficiency, and use fossil fuel energy with possible detrimental effects on health. This is achieved by providing confidence and trust in renewable energy products and those who provide energy-related services. Standards also have the ability to allow those not typically trained in these energy sources to reach a level of understanding that allows them to provide, install or operate systems for themselves or under reduced supervision. This is achieved by providing guidance and best practice in designing, specifying, installing and maintaining the systems. A good example is the set of international standards for rural electrification. Standards also provide an effective framework for harmonizing information flow, understanding technical product design, manufacturing and service requirements, as well as establishing common rules and requirements. Standards should enable all these functions to take place while ensuring there is flexibility for the product, service, system provider and user [35].

\subsection{The "De Facto" and "De Jure" Standards}

A "de facto" standard is one created almost by default because of one dominant player in that industry. A "de facto" standard can also be described as a standard that achieved its status as a result of market competition. For example, Windows for personal computers or VHS for video cartridge recorders are typical de facto standards. A process that a product becomes a standard after it is brought to the market and exposed to competition is called the "classical model". For this instance, such case as Microsoft which maintains monopoly in the market is quite unusual. It is more common that several companies form a group, and those several groups make competition among each other and the winner is determined. A process that a winner is determined after products are brought to the market imposes a heavy burden on companies as they already have completed their capital investment. Consumers also get lost, as even if they purchased products, those styles may no longer be seen in the market some time later. A good example is that consumers felt inconvenience if they had bought video tapes of beta system for some time as they only saw those of VHS system some time later and those tapes previously bought could not be used anymore. Other de facto standards include QWERTY keyboard, Microsoft Word format for documents and Adobe Postscript languages for laser printers [41] [42].

The opposite of an informal "de facto" standard is the "de jure" standard, which means "by force of law". The de jure standards are standards that are developed after going through a certain procedure or official organization. Those standards developed by ISO or IEC are developed through a procedure that experts gather from all over the world and discuss on standardization proposals, which are finally approved through voting by national standards institutes. Japan's standards JIS are also developed going through a procedure that JISC first deliberate a proposal and competent ministers finally make decision to incorporate the proposed standards in the JIS. Korea's Standards KS are developed by Korean Standards Association which is a public organization under the Korean Ministry of Trade, Industry \& Energy (MOTIE) to carry out industrial standardization, certification, and quality promotions thereby contributing to national economy of Korea. However, de jure standards are developed through a transparent and democratic procedure. As companies bring their products to the market based on de jure standards, they do not impose excessive burden on corporations or consumers. However, development of de jure standards takes a long time. They are not suitable for products with short cycle such as IT-related products. Examples of de jure standards include Internet TCP/IP protocol, Wireless 801.11n and Unicode international character encoding [41] [42].

As a result, a new type of standards "forum standards" has been introduced recently, which adopts the positive parts of both de fact standards and de jure standards. Influential companies get together to form a standard before bringing products to the market, so that neither companies nor consumers need to take risks [41].

\subsection{Standards Regulatory Agency in Nigeria}

The only standards regulatory agency in Nigeria is the Standards Organization of Nigeria (SON) which was es- 
tablished by Act. No. 56 of 1971 which vested it with the authority for: standards elaboration, specification, quality assurance system commodities, manufactured industrial and imported products and services. The Act No. 20 of 1976 which amended the previous one conferred on the Honorable Minister of Industry the power to declare Mandatory Industrial Standards in respect of products or processes recommended by the Nigerian Standards Council.

The Act No. 32 of 1984 changed the name of the Organization to Standards Organization of Nigeria (SON) from Nigeria Standards Organization (NSO) to eliminate conflicting identity with the then Nigerian Security Organization. Finally, the Act No. 18 of 1990 conferred on SON partial autonomy from the Ministry of Industry. This amendment gave far-reaching transformation to the organization succession and a common seal, and may sue or be sued in its corporate name. The statutory functions of Standards Organization of Nigeria by Section 3, subsections (1) of 1971 Act No. 56 are as follows:

- To organize test and do everything necessary to ensure compliance with standards designated and approved by the council;

- To undertake investigations as necessary into the quality of facilities, materials and products in Nigeria, and establish a quality assurance system including certification of factories, products and laboratories;

- To ensure reference standards for calibration and verification of measures and measuring instrument;

- To compile an inventory of products requiring standardization;

- To compile Nigeria Industrial Standards;

- To foster interest in the recommendation and maintenance of acceptable standards by industry and the general public;

- To develop method for testing of materials, supplies and equipment including items purchased for use of departments Government of the Federation or State and Private establishment;

- Register and regulate standard marks and specification;

- To undertake preparation and distribution of standard samples;

- To establish and maintain such number of laboratories or other institutions as may be necessary for the performance of its functions under this Act;

- To compile and publish general scientific or other data:

- Resulting from performance of its function under this Act; or

- From other sources when such data are of importance to scientific or manufacturing interest or to the general public and are not available;

- To advise departments of government of the Federation or state on specific problems relating to standards. Nigeria represented by SON is a member of following International Standards Bodies:

- International Organization for Standardization (ISO);

- International Electrochemical Commission (IEC);

- African Organization for Standardization (ARSO).

Presently, Nigeria (SON) is a member of the International Organization for Standardization (ISO) with Participating (P-Member) and Observer Member (O-Member) in various Technical Committees (TC) and Project Development Committees (PDCs) [43]. Among all the standards available in the SON, there is none that is responsible for the standards of renewable energy technologies as at present. However, the next section describes a developmental process in which a renewable energy standard could be formulated and adapted by the SON.

\section{Development of Renewable Energy Standards}

Currently, the SON maintains 33 Standing Technical Committees (TC) which also have sub technical committees that deals with specific issues. The various TC usually creates a forum wherein the various experts are harnessed in the development of standards. A draft standard is usually prepared by the SON Technical Officers in the Organization depending upon the priority or work programme of the directorate and on the need or demand from the stakeholders. The officers, thereafter collect the relevant scientific data related to the draft standard under development from technical literatures including journals, laboratory tests results and factory inspections among others. The draft is then sent out to the TC members for review. The comments are received and collate the and the meeting of the relevant TC is held to review the comments and evaluated all quality parameters being prescribed are accepted by consensus to be adequate for approval by the Nigeria Standards Council or in its absence the Honorable Minister of Supervision Ministry of the Standards Organization of Nigeria, Approval of 
National Standards. The responsibility of authorization of National Standards as per the Act establishing SON is vested in the Organization's Governing Council also referred to as Nigeria Standards Council. In absence of the Council, the Honorable Minister, Federal Ministry of Trade and Investments has the responsibility to approve a standard for use. Apart from development of new standards, existing standards are revised or reviewed so that the outdated matches with the current quality parameters. The procedure for review of standards is the same with that of drafting new ones. Standards are reviewed after three years, if there is technological development in the sector concerned or where inadequacies are observed. When standards reviewed and are no longer relevant for the purposes they were developed are withdrawn [43].

As earlier discussed in this study, the SON does not have any form of standards for renewable energy technologies present. However, development of renewable energy standards would be a welcomed development. The testing and proper certification of renewable energy equipment for off-grid or small scale application will still face some challenges. These challenges could come from the political class or importers who import substandard products into the country. Most renewable energy products are imported from China into the Nigerian market without proper product certification. Some of the imported technologies include solar panels, inverters, energy storage systems, small hydropower (SHP) units and wind turbines.

The deployment of renewable energy depends on some issues which are external to standards like Feedin-Tariffs (FiTs), planning, environmental factors, building regulation and economic development. Standards will be used along with various policies, certification and regulation to open up renewable energy market.

Developing renewable energy standards involves high cost and is time consuming, this has hindered actors from participating in the process of renewable energy standards development. Development of renewable energy standards can be achieved if the SON collaborate with the ECN and other relevant bodies in engaging more external stakeholders who will make use of reports, case studies, research articles and various workshops to ensure that proper standards are developed for renewable energy technologies. These activities will improve the mix of experts that will in turn improve the quality of the standards under development. The SON will need to increase its TC to accommodate experts in the field of renewable energy. The SON should also engage specific projects related to renewable energy standards development as well as promote knowledge dissemination in renewable energy technologies.

\subsection{Cost of Standards}

Some challenges are faced by standard bodies in the developing countries is have the right standards in the first place and to have access to purchase the standards and also to keep them up to date. The cost implications for the standard organizations in the developing countries and emerging markets can make the difference between adopting the already existing internationally developed standards, producing local requirements or the complete rejection of the standards. The cost of standards may be seen as a barrier to the adoption of standards, but in the case of Nigeria, it should be seen as means to ensure that her citizens are protected from poor quality renewable energy technologies manufactured with the best practice of standardization. However, some recommendations for small renewable energy and hybrid systems are provided in Table 2 for rural electrification (see [35]).

\subsection{Recommended Standards for Renewable Energy Technologies}

Below are some recommended standards currently available through the International Organization for Standardization (ISO). These recommended standards should be used as an immediate measure to address the issue of substandard importation of renewable energy technology.

\section{- ISO/TC 180 Solar Energy}

Standardization in the field of solar energy utilization in space and water heating, cooling, industrial process heating and air conditioning.

\section{- IEC/TC 82 Solar Photovoltaic Energy System}

Includes the entire field from light input to a photovoltaic cell to and including the interface with the electrical system(s) to which energy is supplied.

\section{- IEC/TC 88 Wind Turbines}

These standards address design requirements, engineering integrity, measurement techniques and test procedures. Their purpose is to provide a basis for design, quality assurance and certification. The standards are concerned with all subsystems of wind turbines, such as mechanical and internal electrical systems, support struc- 
Table 2. Recommendations for small renewable energy and hybrid systems for rural electrification [35].

\begin{tabular}{|c|c|c|}
\hline Standards No. & Standard Name & $\begin{array}{l}\text { Cost of Standards } \\
\text { (USD), [Cost in NGN }]^{*}\end{array}$ \\
\hline IEC/TS 62257-9-1 & $\begin{array}{l}\text { Recommendations for small renewable energy and hybrid systems for rural } \\
\text { electrification-Part 9-1: Micro-power systems }\end{array}$ & $252.31[41441.58]$ \\
\hline IEC 60364 (all parts) & $\begin{array}{l}\text { Low-voltage electrical installations } \\
\text { Note: All parts would equate to } 32 \text { standards documents }\end{array}$ & $4284.00[703641.27]$ \\
\hline $\begin{array}{l}\text { IEC 60364-5-53:2001 } \\
\text { included in all } \\
\text { parts above }\end{array}$ & $\begin{array}{l}\text { Electrical installations of buildings-Part 5-53: Selection and erection of } \\
\text { electrical equipment-Isolation, switching and control }\end{array}$ & Not Available** \\
\hline IEC 60529 & Degrees of protection provided by enclosures (IP Code) & $262.50[43115.27]$ \\
\hline IEC/TS 62257-2:2004 & $\begin{array}{l}\text { Recommendations for small renewable energy and hybrid systems for rural } \\
\text { electrification-Part 2: From requirements to a range of electrification } \\
\text { systems }\end{array}$ & $283.22[46518.51]$ \\
\hline IEC/TS 62257-4:2005 & $\begin{array}{l}\text { Recommendations for small renewable energy and hybrid systems for rural } \\
\text { electrification-Part 4: System selection and design }\end{array}$ & $188.81[31011.79]$ \\
\hline IEC/TS 62257-5:2005 & $\begin{array}{l}\text { Recommendations for small renewable energy and hybrid systems for rural } \\
\text { electrification-Part 5: Protection against electrical hazards }\end{array}$ & 188.81 [31011.79] \\
\hline IEC/TS 62257-6:2005 & $\begin{array}{l}\text { Recommendations for small renewable energy and hybrid systems for rural } \\
\text { electrification-Part 6: Acceptance, operation, maintenance and } \\
\text { replacement }\end{array}$ & $94.41[15506.72]$ \\
\hline IEC/TS 62257-7-1:2006 & $\begin{array}{l}\text { Recommendations for small renewable energy and hybrid systems for rural } \\
\text { electrification-Part 7-1: Generators-Photovoltaic arrays }\end{array}$ & $293.71[48241.47]$ \\
\hline IEC/TS 62257-7-3:2008 & $\begin{array}{l}\text { Recommendations for small renewable energy and hybrid systems for rural } \\
\text { electrification-Part 7-3: Generator set-Selection of generator sets for } \\
\text { rural electrification systems }\end{array}$ & 209.79 [34457.73] \\
\hline IEC/TS 62257-9-2:2006 & $\begin{array}{l}\text { Recommendations for small renewable energy and hybrid systems for rural } \\
\text { electrification-Part 9-2: Micro-grids }\end{array}$ & $251.75[41349.6]$ \\
\hline IEC/TS 62257-9-4:2006 & $\begin{array}{l}\text { Recommendations for small renewable energy and hybrid systems for rural } \\
\text { electrification-Part 9-4: Integrated system-User installation }\end{array}$ & $25.87[4249.11]$ \\
\hline & Total & 6435.18 [1056969.7] \\
\hline
\end{tabular}

Note: *NGN means Nigerian naira. The currency conversation was made on $4^{\text {th }}$ October, 2014; **The cost information was not available at the time of publication.

tures and control and protection systems. They are intended to be used together with appropriate IEC/ISO standards.

\section{- IEC/TC 4}

Hydraulic rotating machinery and associated equipment allied with hydro-power development.

\section{- ISO/TC 238 Solid Biofuels}

Standardization of terminology, specifications and classes, quality assurance, sampling and sample preparation and test methods in the field of raw and processed materials originating from arboriculture, agriculture, aquaculture, horticulture and forestry to be used as a source for solid biofuels. Excluded: areas covered by ISO/TC 28/SC 7 Liquid biofuels, ISO/TC 193 Natural gas.

\section{- ISO/PC 248 Sustainability Criteria for Bioenergy}

Standardization in the field of sustainability criteria for production, supply chain and application of bioenergy. This includes terminology and aspects related to the sustainability (e.g. environmental, social and economic) of bioenergy.

\section{- ISO/TC 255 Biogas}

Standardization in the field of biogas.

\subsection{Recommendations to Standards Organization of Nigeria}

The Standards Organization of Nigeria which is the standard body in Nigeria will need to make some adjustment 
to its policy in order to protect the citizens of Nigeria from the influx of poor quality renewable energy products into the country. Some recommendations are given below:

- Develop standard compliance cooperation with foreign countries where most of the renewable energy products are manufactured;

- Development of renewable energy standards with the cooperation of international standard bodies in the field of renewable energy;

- Promote the training of experts through development programmes, constructing standard databases, designating a permanent agency or commission for the promotion and implementation of renewable energy product standard;

- Implement laws for the promotion of renewable energy standardization plans, organization, budget and human resource development;

- Revise a number of laws and articles to ensure that renewable energy standardization is embedded in the political framework;

- Ensure that each renewable energy product imported into the country by an importer are given After Sales Service (ASS) for up-to 5 years from the time of purchase to the consumer.

\section{Conclusions}

For sustainable energy to be achieved in any country, clean energy development has to be a national priority. The issues of climate change have alerted most governments around the world to mitigate global warming by moving towards renewable energy adoption and incorporation into their energy mix. The manufacturing of renewable energy technologies like solar panels, solar thermal, inverters, energy saving systems, various kinds of wind turbines and hydropower systems has increased in recent times. Most countries like South Korea, Japan, China and the US manufacture these renewable energy technologies according to their own specification and standards and export it to other countries that do not have the technical expertise or resources to produce theirs. While this may sound good, some countries do manufacture substandard renewable energy technologies and export it to developing countries that may not have proper standards bodies to check the imported products into their market.

Nigeria has abundant renewable energy resources but do import the technology which is able to harness the renewable energy potential. These technologies are usually substandard and are dangerous to her citizens. This study has discussed the necessity of the development of standards for renewable energy technology which is imported, stressed the need to develop local content in the field of renewable energy and given some recommended standards that could be applied. Nigeria has a standard body which is the Standards Organization of Nigeria (SON) but no standards have been made available for renewable energy technologies. However, the country depends on standards set by other countries that export the technologies.

However, some immediate measures should be put in place by the SON to protect Nigerian citizens from the various substandard renewable energy technologies which include solar panels, inverters, and energy-saving systems. As an immediate measure, the SON should ensure that the technologies which are imported into the country are checked for international standards which are usually granted by International Electrochemical Commission (IEC) and also apply the given recommendation in this study. This will stop the influx of substandard renewable technologies while the SON develops its own standards.

This study strongly believes that the development of standards for renewable energy technologies is of great importance to secure the citizens of Nigeria and also to fast track the development of renewable energy in Nigeria. The study focused on the necessity for the development of standards for renewable energy technologies and recommended some standards but did not propose any standards. Thus, more studies should be undertaken to come up with a proper standard that can be submitted to the SON.

\section{References}

[1] Sambo, A.S. (2005) Renewable Energy for Rural Development: The Nigerian Perspective. ISESCO Science and Technology Vision, 1, 12-22.

[2] Oyedepo, S.O. (2012) Energy Efficiency and Conservation Measures: Tools for Sustainable Energy Development in Nigeria. International Journal of Energy Engineering, 2, 86-98.

[3] Okafor, E.N.C. and Joe-Uzuegbu, C.K.A. (2010) Challenges to Development of Renewable Energy for Electric Power 
Sector in Nigeria. International Journal of Academic Research, 2, 211.

[4] Patlitzianas, K., Flamos, A., Doukas, H., Kagiannas, A. and Psarras, J. (2007) Promoting Renewable Energies and Energy Efficiency through the CDM Funding Options. 2004 New and Renewable Energy Technology, 1.

[5] European Commission (2003) Second ECCP Progress Report: Can We Meet Our Kyoto Targets? European Commission, Brussels.

[6] Why Solar Energy Is Underutilized in Nigeria—Suleiman (2014). www.leadership.ng/news/347736/solar-energy-underutilised-nigeria-suleiman

[7] Shaaban, M. and Petinrin, J.O. (2014) Renewable Energy Potentials in Nigeria: Meeting Rural Energy Needs. Renewable and Sustainable Energy Reviews, 29, 72-84. http://dx.doi.org/10.1016/j.rser.2013.08.078

[8] Vincent, E.N. and Yusuf, S.D. (2014) Integrating Renewable Energy and Smart Grid Technology into the Nigerian Electricity Grid System. Smart Grid and Renewable Energy, 5, 220-238. http://dx.doi.org/10.4236/sgre.2014.59021

[9] Sambo, A.S. (2009) Strategic Developments in Renewable Energy in Nigeria. International Association for Energy Economics, 16.

[10] Uduma, K. and Arciszewski, T. (2010) Sustainable Energy Development: The Key to a Stable Nigeria. Sustainability, 2, 1558-1570. http://dx.doi.org/10.3390/su2061558

[11] Nadabo, S.L. (2010) Renewable Energy as a Solution to Nigerian Energy Crisis.

[12] Energy Commission of Nigeria (ECN) (2009) Renewable Energy Master Plan.

[13] Ilenikhena, P.A. and Ezemonye, L.I.N. (2010) Solar Energy Applications in Nigeria. WEC MONTREAL.

[14] Yearly Average of Daily Sun in Nigeria. http://www.soda-is.com/eng/nigeria_en.html

[15] Adeoti, O., Oyewole, B.A. and Adegboyega, T.D. (2001) Solar Photovoltaic-Based Home Electrification System for Rural Development in Nigeria: Domestic Load Assessment. Renewable Energy, 24, 155-161. http://dx.doi.org/10.1016/S0960-1481(00)00188-9

[16] Bugaje, I.M. (2006) Renewable Energy for Sustainable Development in Africa: A Review. Renewable and Sustainable Energy Reviews, 10, 603-612. http://dx.doi.org/10.1016/j.rser.2004.11.002

[17] Oyedepo, S.O. (2012) On Energy for Sustainable Development in Nigeria. Renewable and Sustainable Energy Reviews, 16, 2583-2598. http://dx.doi.org/10.1016/j.rser.2012.02.010

[18] Energy Commission of Nigeria (2006) Energy Commission of Nigeria (ECN) Renewable Energy Master Plan. Energy Commission of Nigeria, Government of Nigeria, Abuja.

[19] Nigeria Wind Energy. http://www.neenigeria.com/Nigeria_wind_NEW.png

[20] Bada, H.A. (2011) Managing the Diffusion and Adoption of Renewable Energy Technologies in Nigeria. World Renewable Energy Congress, Linkoping, 8-13 May 2011, 2642-2649.

[21] Mohammed, Y.S., Mustafa, M.W., Bashir, N. and Mokhtar, A.S. (2013) Renewable Energy Resources for Distributed Power Generation in Nigeria: A Review of the Potential. Renewable and Sustainable Energy Reviews, 22, 257-268. http://dx.doi.org/10.1016/j.rser.2013.01.020

[22] Sambo, A.S. (2009) The Place of Renewable Energy in Nigeria Energy Sector. World Future Council Workshop on Renewable Energy Policies, Addis Ababa, 10 October 2009, 5.

[23] Ohunakin, O.S. (2010) Energy Utilization and Renewable Energy Sources in Nigeria. Journal of Engineering and Applied Sciences, 5, 171-177. http://dx.doi.org/10.3923/jeasci.2010.171.177

[24] The Nigerian Water Ways (2014). http://www.safty4sea.com/

[25] Iloeje, O. (2002) Renewable Energy Development in Nigeria: Status \& Prospects. Proceedings of a National Workshop on Energizing Rural Transformation in Nigeria: Scaling up Electricity Access and Renewable Energy.

[26] Ikuponisi, F.S. (2004) Status of Renewable Energy in Nigeria. One Sky Energetic Solutions Conference, Nigeria, 21-27 November 2004, Background Paper.

[27] Abumere, S.I., Okafor, S.I. and Oluwasola, O. (2002) Rural Infrastructure and the Development Process in Rural Nigeria (No. 36). Development Policy Centre.

[28] Sambo, A.S. (2010) Renewable Energy Development in Nigeria: A Situation Report. World Future Council/Strategy Workshop on Renewable Energy, Accra, 21-24 June 2010.

[29] Spalding-Fecher, R., Winkler, H. and Mwakasonda, S. (2005) Energy and the World Summit on Sustainable Development: What Next? Energy Policy, 33, 99-112. http://dx.doi.org/10.1016/S0301-4215(03)00203-9

[30] Efurumibe, E.L. (2013) Barriers to the Development of Renewable Energy in Nigeria. Scholarly Journal of Biotechnology, 2, 11-13.

[31] Standardization (2014). http://www.encyclopedia2.thefreedictionary.com/ 
[32] Sykes, A.O. (1995) Product Standards for Internationally Integrated Goods Markets. Brookings Institution, Washington DC.

[33] International Standard Organization (ISO). http://www.iso.org/

[34] World Trade Organization (WTO). http://www.wto.org/

[35] REP, IRENA (2013) International Standardisation in the Field of Renewable Energy.

[36] Marshall, A. (1919) Industry and Trade: A Study of Industrial Technique and Business Organization and of Their Influences on the Condition of Various Classes and Nations. MacMillian and Co. Limited, London, New York.

[37] David, P.A. and Greenstein, S. (1990) The Economics of Compatibility Standards: An Introduction to Recent Research. Economics of Innovation and New Technology, 1, 13-41.

[38] Hawkins, R., Mansel, R. and Skea, J., Eds. (1995) Standards, Innovation and Competitiveness: The Politics and Economics of Standards in Natural and Technical Environment Edward Elgar, Aldershot, Brookfield, p. 1.

[39] IEEE Standards Association (2014) How Are Standards Made? http://www.standards.ieee.org/develop/process.html

[40] Try Standards: Global Standards Education and Standards Search. http://www.trystandards.org/mod/page/view

[41] The Difference between De Facto Standards and De Jure Standards (2014). http://www.ncos.gr.jp/English.files/e_newpage51

[42] De facto and De Jure Standards (2014). http://www.teach-ict.com/as_a2_ict_new/ocr/A2_G063/333_networks_coms/standards/miniweb/pg3

[43] Standards Organization of Nigeria (2014). http://www.son.gov.ng/ 
Scientific Research Publishing (SCIRP) is one of the largest Open Access journal publishers. It is currently publishing more than 200 open access, online, peer-reviewed journals covering a wide range of academic disciplines. SCIRP serves the worldwide academic communities and contributes to the progress and application of science with its publication.

Other selected journals from SCIRP are listed as below. Submit your manuscript to us via either submit@scirp.org or Online Submission Portal.
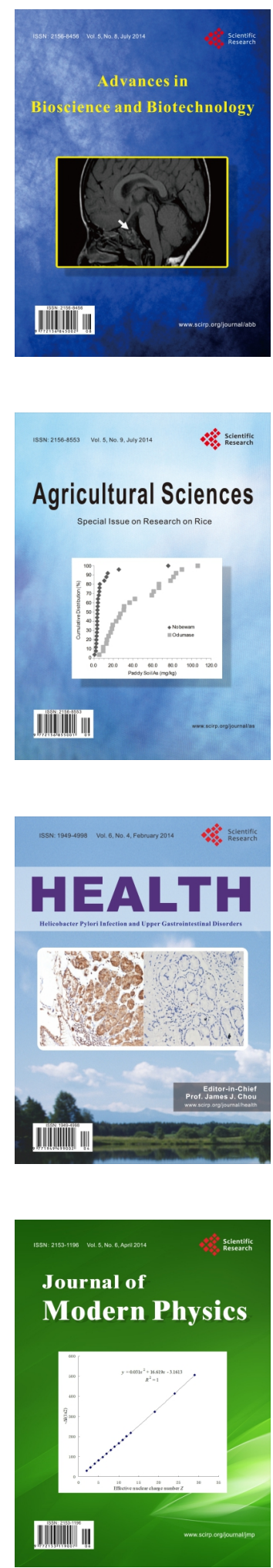
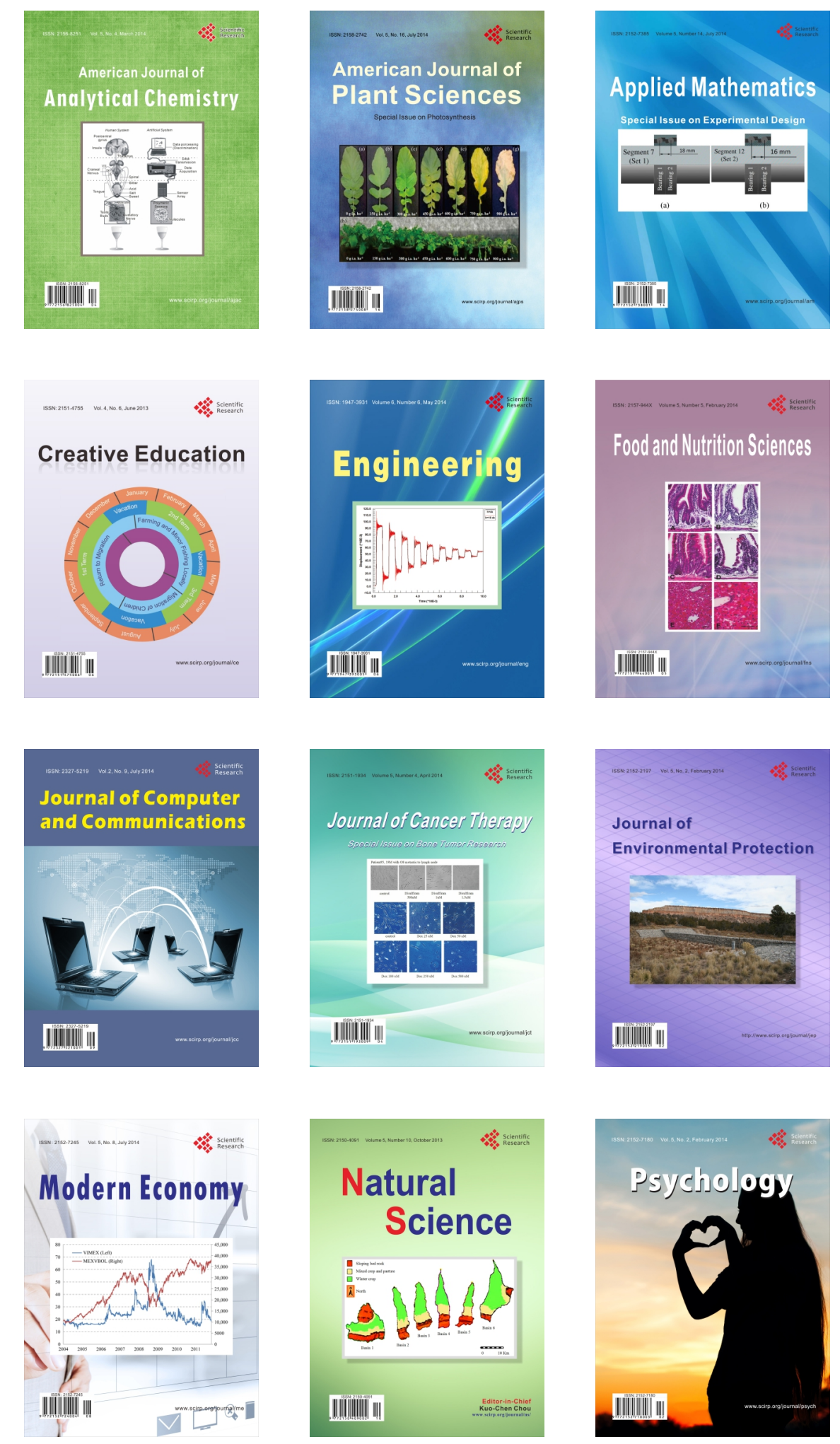